\title{
GÊNERO E SEXUALIDADES NOS LIVROS DIDÁTICOS DE SOCIOLOGIA APROVADOS PELO PNLD 2015
}

\author{
GENDER AND SEXUALITY IN SOCIOLOGY TEXTBOOKS APPROVED BY PNLD 2015
}

\section{Resumo}

Propomos analisar como gênero e sexualidade emergem nos livros didáticos de sociologia aprovados no PNLD 2015. Dos seis livros, apenas três (Sociologia; Sociologia em Movimento; Sociologia para Jovens do Século XXI) dedicam capítulos inteiros a este campo de estudos; nos outros (Tempos Modernos, Tempos de Sociologia; Sociologia Hoje; Sociologia para o Ensino Médio) encontramos fragmentado esparsos nos demais capítulos. Em Sociologia, focando-se nos estudos sobrefamília e parentesco, encontramos diálogo com teóricos clássicos (Durkheim, Giddens, Bourdieu), mas reduzida referência à epistemologia feminista. Em Sociologia em Movimento há constante relação com trabalho e feminismo classista, observável no referencial teórico (Angela Davis, Elisabeth Lobo, Cristina Brueschini). Por fim, em Sociologia para Jovens do Século XXI, dá-se mais atenção aos estudos de gênero, com diálogo entre autoras clássicas e contemporâneas, mostrando a trajetória dos conceitos, além da influência de outras áreas, como Kinsey/Psicologia.

Palavras-chave: Sociologia. Livro didático. PNLD. Gênero. Sexualidades.

\begin{abstract}
We propose to analyze how gender and sexuality appears on the sociology didactic books approved in the National TextBook Plan (PNDL) of 2015. From the six books approved by the Plan, only three (Sociologia; Sociologia em Movimento; Sociologia para Jovens do Século XXI) dedicate full chapters to the studies about Gender and Sexuality; on the others books (Tempos Modernos, Tempos de Sociologia; Sociologia Hoje; Sociologia para o Ensino Médio) we only found this theme fragmented. In the textbook called Sociologia, focusing on family and kindship, we notice a dialogue with the authors of the classical theory (Durkheim, Giddens, Bourdieu), but references about the feminist epistemology were very little. In Sociologia em Movimento there is a constant relation with themes like work and classist feminism, what is possible to observe in the theoretical reference (Angela Davis, Elisabeth Lobo, Cristina Brueschini). At last, the textbook Sociologia para Jovens do Século XXI,
\end{abstract}

Diane Macedo

Universidade Federal de Santa Catarina. E-mail: dianedemacedo@yahoo.com.br

Heloisa C. Domingos

Universidade Federal de Santa Catarina. E-mail: heloisadomingos@hotmail.com

Mariane S. Pisani

Universidade Federal de Santa Catarina. E-mail: marianepisani@gmail.com

Natan S. Kremer

Universidade Federal de Santa Catarina. E-mail: natan_kremer@hotmail.com

Rachel T. S. Abrão

Universidade Federal de Santa Catarina. E-mail: rachelabrao@gmail.com 
gives more attention to the gender studies, bringing a dialogue between classical and contemporary women writers, showing the trajectory of the concepts, beyond the influence of other areas of knowledge, such as Kinsey/Psychology.

Keysword: Sociology. Textbooks. PNLD. Gender. Sexuality.

\section{Introdução}

Neste artigo buscamos apresentar e discutir o modo como os estudos de gênero e sexualidade são abordados (ou não) nos livros didáticos de sociologia aprovados pelo Programa Nacional do Livro Didático (PNLD) para o triênio 2015-2017, dando atenção especial para as figuras utilizadas nos capítulos destinados à temática.

Compreendemos que os estudos de gênero e sexualidades em sala de aula são temas em acirrada disputa, tendo em vista: a) a não regulamentarização do Ministério da Educação (MEC) no que tange a problemática; b) a proposta de lei intitulada Programa Escola sem Partido, que tem por um dos objetivos suprimir a temática das discussões em sala alegando que ela fere a moral, a instituição da família e a formação do Estado; c) a extinção, na gestão de Michel Temer, da Secretaria de Políticas para as Mulheres da Presidência da República, responsável pela produção de políticas públicas que tangenciam a problemática de gênero e sexualidade. Posto isso, é preciso saber como estes temas e discussões são abordados nos livros didáticos aprovados pelo PNLD de 2015 e como os problemas - de pesquisa, epistemológicos, sociais e culturais - deste campo de conhecimento são levados à sala de aula.

Tal investigação nos parece pertinente na medida em que não encontramos diretrizes no Ministério da Educação que regularizem esta proposta curricular. Dessa forma, a temática pode ou não ser trabalhada em sala de aula, a partir da formação (ou não) de professoras e professores. Além disso, o forte conservadorismo que se instaura na sociedade brasileira contemporânea soma-se à crescente violência contra às mulheres e à população LGBT. Inserir estudos de gênero e sexualidade dentro de sala de aula é contemplar a diversidade e, também, uma tentativa de amenizar as desigualdades e crimes de ódio (homofobia, lesbofobia, transfobia, bifobia, misoginia) crescentes na atualidade, pensando em uma educação para a autonomia do sujeito e o respeito à diversidade.

\section{$O$ conceito de gênero}

As noções de feminino e masculino, papéis sociais de mulheres e homens, estão ancoradas em nossa sociedade a uma dimensão biológica. São comuns e constantes os discursos produzidos que fomentam o corpo como resultado biológico, e os hormônios parecem ser elemento de destaque nessa discussão. A testosterona, ligada à agressividade; o estrogênio, à sensibilidade. Ou seja, essas afirmações conectam os 
sujeitos ao biológico e apontam para uma predeterminação de acordo com a genitália do indivíduo. Assim, ao nascer-se fêmea são diversas as características preconcebidas impostas ao sujeito para formatar os modos de ser e sua subjetividade; o mesmo movimento atinge os indivíduos que nascem machos. A biologia, entretanto, pode ser questionada. Não que os corpos não apresentem características distintas, mas a constituição do comportamento humano está atrelada ao seu envolvimento em grupos, em um processo de aprendizado: a socialização entre pares é o principal mecanismo para a consolidação do sujeito. Assim, o que as ciências humanas perceberam é que é na sociedade, por meio das interações, que aprendemos e incorporamos os significados de feminino e masculino.

$\mathrm{O}$ conceito de gênero com o qual estamos habituados contemporaneamente é resultado de discussões que tomaram fôlego nos anos 1970, mas que pairavam à cena já nas primeiras décadas do século XX, no que hoje conhecemos como Sufrágio Feminino. As feministas da primeira onda, defendendo a ideia radical de que homens e mulheres eram iguais, lutaram pelo direito ao voto, dentre outras importantes conquistas. Ao mesmo tempo, diversas intelectuais das ciências humanas passaram a questionar-se sobre as diferenças entre homens e mulheres. Simone de Beauvoir é uma representante importante dessa história, ao propor, em 1941, em seu livro célebre, que não se nasce mulher, mas que se torna. Em O Segundo Sexo(2009) nos deparamos com reflexões sobre as desigualdades entre homens e mulheres na sociedade ocidental, onde a autora nos apresenta uma crítica à determinação natural dos corpos, apontando para a ineficácia da ideia de sexo biológico para explicar as diferenças da masculinidade e da feminilidade.

Anteriormente a Simone de Beauvoir, Margareth Mead publicou, em 1935, a obra Sexo e Temperamento (2011). Ainda sem usar a categoria gênero, a autora propunha a noção de "temperamento" para explicar as diferenças entre homens e mulheres a partir da análise das práticas culturais de três grupos étnicos da Nova Guiné. Por meio da argumentação antropológica da cultura, a autora buscou entender as peculiaridades dos Arapesh, dos Mundugomor e dos Tchambuli nos modos distintos como se relacionavam em relação ao feminino e ao masculino.

Embora a transposição de categorias ocidentais para o estudo de grupos com outra estruturação social seja uma crítica costumeira à obra de Margareth Mead, sua contribuição para o campo dos estudos de gênero e sexualidade não deve ser esquecida ou tomada de forma a-histórica. O que a autora percebeu em sua análise é que, no primeiro grupo étnico estudado, os Arapesh, tanto homens quanto mulheres poderiam ser considerados, conforme a cultura ocidental, detentores de uma sensibilidade "afetiva", "maternal", com boas relações com os demais membros do grupo. No segundo, a sua vez, todos eram agressivos. Entre os Mundugomor a violência reinava entre homens e mulheres. Nessas duas sociedades, aponta a autora, os papéis sociais não eram definidos de acordo com as diferenças biológicas, não divergiam. Nos Tchambuli, a sua vez, Mead percebeu uma inversão dos papéis sexuais ocidentais: neste grupo étnico, era atividade dos homens o cuidado das crianças, a gentileza, a delicadeza; ao passo em que cabia às mulheres a força, a bravura, 
a guerra. Assim, o que a autora demonstrou, de forma pioneira, é o fato de que o comportamento de homens e mulheres não está atrelado aos fatores biológicos, mas construídos por meio da socialização e da ordem cultural.

$\mathrm{O}$ que estava sendo posto neste momento, então, é que nascer macho ou fêmea não correspondia a ser homem ou mulher. $\mathrm{O}$ estudo de Mead nos mostrou que as representações sociais de gênero são resultado de um aprendizado dentro do grupo ao qual o indivíduo está submetido. Assim, os gestos, os modos de vestir, as brincadeiras e interesses, ou seja, a forma de se relacionar com as demais pessoas, não são elaboradas de formas iguais em todas as sociedades e essa variação nos mostra como o gênero é resultado de processos históricos de socialização e aprendizado.

Desse modo, o gênero aparece como um dispositivo que atua na constituição das subjetividades. Esse dispositivo aponta ao que é esperado do comportamento de meninas e meninos e faz com que os indivíduos vão se normalizando às expectativas sociais. É nesse processo, que começa ainda antes do nascimento, quando a família escolhe a cor das paredes do quarto da criança, que a subjetividade começa a se formar e, ao longo dos anos, por meio do controle externo exercido constantemente, os indivíduos vão se formando como sujeitos - e, como tal, como homens e mulheres, apreendendo e constituindo a identidade de gênero correspondente.

É na família onde se escuta pela primeira vez que "menino não chora" e que "menina deve cuidar das bonecas", desenvolvendo, nos rapazes, um bloqueio das emoções e, nas garotas, uma ética do cuidado: "rosa é cor de menina e azul cor de menino"; "somente as meninas devem ajudar nas tarefas domésticas"; "garotos jogam futebol". Assim, desde a primeira infância cabe a meninas e meninos um aprendizado das diferentes possibilidades do que podem ou não fazer, consolidando assim comportamentos distintos entre os gêneros. Brincadeiras, tarefas, comentários aparentemente "inofensivos" vão formando, legitimando, desde cedo, as diferenças entre homens e mulheres, entre público e privado. O grande problema dessa socialização é condicionar o comportamento a uma normatividade prescrita de forma arbitrária, e estigmatizar quem não se submete a tal padrão. Desse modo consegue, violentando os sujeitos, a manutenção do status quo.

Essas ações aparentemente isoladas que tangenciam as experiências da infância se repetem e atingem diretamente as escolhas de adultos, pois são nas relações com a família, com a escola e com a comunidade na qual a família está inserida que será formulado o campo de possibilidades (Velho, 2013) desses sujeitos. Assim, a escolha de trabalhos, por exemplo, são resultados de processos sociais: não é biológica a escolha de homens trabalharem na construção civil e mulheres como empregadas domésticas; ou homens serem chefes em grandes empresas ao passo em que às mulheres cabem as salas de espera, atendendo telefonemas. E se hoje homens e mulheres conseguem, em alguma medida, equalizar as fronteiras entre os campos profissionais, qual a razão para umas ainda receberem menos que outros?

São as hierarquias de gênero que marcam essa distinção salarial, mas não apenas. Esse sistema hierárquico aponta para uma assimetria que marca a desigualdade de oportunidades e direitos entre homens e mulheres. Essa hierarquia organiza as 
relações sociais e estabelece deveres específicos, além de atribuir maior valoração para algumas atividades em detrimento de outras. Assim, a escola tem um papel fundamental na desconstrução das diferenças de gênero, pois é no debate que as desigualdades podem ser desnaturalizadas, mostrando como essa relação é resultado de um contexto histórico-social ao qual nós, indivíduos, estamos submetidos. Nas palavras de Joan Scott:

Examinar gênero concretamente, contextualmente e de considerá-lo um fenômeno histórico, produzido, reproduzido e transformado em diferentes situações ao longo do tempo. Esta é ao mesmo tempo uma postura familiar e nova de pensar sobre a história. Pois questiona a confiabilidade de termos que foram tomados como auto-evidentes, historicizando-os. A história não é mais a respeito do que aconteceu a homens e mulheres e como eles reagiram a isso, mas sim a respeito de como os significados subjetivos e coletivos de homens e mulheres, como categorias de identidades foram construídos (Scott, 1994: 19).

\section{Sexo e Sexualidade}

Ao avistarmos uma mulher grávida, um de nossos primeiros questionamentos é saber se espera uma menina ou um menino. Por meio dessa resposta, uma sequência de noções e perspectivas, preconceitos e expectativas, são organizados em nosso raciocínio e passam a constituir nossa ideia da criança: gostos, desejos, cores, afetos e outros mecanismos passam a marcar o que ainda é um feto. Deste modo, não é incomum encontrarmos mães e pais ansiosos para saber o sexo do bebê, fazendo diversos exames e preparando um imaginário simbólico a partir do dado biológico. Enxoval, brinquedos, cores da parede do quarto são marcas simbólicas que buscam normatizar as experiências desses bebês, ensinando desde os primeiros momentos estereótipos de gênero.

Assim, é perceptível em nossa sociedade uma associação direta entre o sexo biológico e a identidade de gênero. O que vimos até agora, à luz das ciências humanas, é que o gênero é uma construção social, e não um dado biológico determinado hormonalmente. Indo mais longe, encontramos apoio nas investigações de Thomas Laqueur (2001), autor que nos mostrará que também o sexo é uma construção social. Até o século XVIII, o conhecimento científico considerava que o aparelho feminino, a vagina, tratava-se de um pênis invertido e, seguindo essa lógica, os ovários seriam uma versão internalizada dos testículos. Desse modo, as mulheres se encontravam em um estágio "formal" de discriminação, ao serem consideradas inversões dos homens. Mas, ao mesmo tempo, outra relação era estabelecida com o corpo e, não esquecendo a concepção de que a mulher era inferior ao homem, era valorizado o 
prazer sexual feminino - para o bom desenvolvimento da reprodução. O que estava posto, no plano de fundo, era o modelo de um sexo único, que apenas no século XIX com suas transformações políticas, econômicas e culturais, reelaborou este modelo, passando a reconhecer a existência de dois sexos e marcando suas diferenças: um corpo feminino, um corpo masculino.

Essa concepção histórica nos dá possibilidade de entender, pois, que o sexo é uma categoria utilizada para expressar uma ordem hierárquica entre homens e mulheres (como o jargão "sexo frágil"). Tal como a ideia de raça, que foi utilizada na legitimação da escravidão, a categoria "sexo" naturaliza e tenta tornar o corpo em algo estático, mesmo que esse processo resulte em violências que normatizam os corpos e as relações. Nos dizeres de Monique Wittig (1992): "a ideologia da diferença sexual funciona como uma censura em nossa cultura, que mascara, por naturalização, a oposição social entre homens e mulheres. Masculino/feminino, macho/fêmea são categorias que servem para ocultar o fato de que diferenças sociais sempre pertencem a uma ordem econômica, política, ideológica. Todo sistema de dominação estabelece divisões no nível material e econômico".

Michel Foucault (2014), em sua clássica trilogia História da Sexualidade, argumentou que a sexualidade passou a ser um tema para compreender as sociedades ocidentais, e apontou como prelúdio para as transformações que marcam os séculos XVI e XVII. Nesses dois séculos o colonialismo levou ao contato com outros povos e, por consequência, gerou a produção de discursos sobre estes. Conforme nos conta o autor, ao mesmo tempo em que se considerava que o sexo era um dado biológico dado pela natureza, a sexualidade era tida como uma expressão da animalidade humana. Foucault, a sua vez, reconhece os dispositivos civilizatórios que, ao mesmo tempo em que controlam a sexualidade, também incitam comportamentos sexuais específicos, originados nas relações sociais. É por meio dessa argumentação que o autor compreenderá a sexualidade como um dispositivo, é dizer, como uma rede articulada que agrupa, conecta as dimensões da experiência, passando pelo desejo, pelas formas da relação, a conduta, o afeto, as sensações e funções biológicas. Assim, compreender a sexualidade como dispositivo é deparar-se com o resultado de uma construção da sociedade. E sendo fabricada, ela responde a um determinado modo de funcionamento. De acordo com Tânia Navarro Swain (2006), o dispositivo da sexualidade tem preponderância sobre as demais dimensões da vida, e as regula e orienta.

Como vimos, as categorias de sexo, gênero e sexualidade são fundamentais na constituição da sociedade, visto que "o gênero é um primeiro modo de dar significado às relações de poder” (Scott, 1990, p. 14). Essas categorias possuem como característica a possibilidade de nortear os desejos, pulsões, modos de ser/estar no mundo; em suma, a subjetividade.

Há, entretanto, uma ordem arbitrária que marca o que é "normal" e "aceitável" na constituição dessas subjetividades, em detrimento do que recebeu, ao longo da história das ciências sociais, diversos nomes: comportamento desviante, desvio, comportamento patológico. Aqui, optamos por adotar o conceito 
desenvolvido por Gayatri Spivak (2010), teórica feminista indiana: subalternidade. A heteronormatividade é um bom exemplo para pensarmos neste comportamento "normal", visto ser uma construção social que condiciona a associação entre sexo, gênero e sexualidade sob tal fórmula: macho, masculino, heterossexual; e fêmea, feminina, heterossexual.

A qualquer indício de comportamento desviante, de quebra com a norma, as situações de violência tomam a cena. Um bom exemplo são homens que possuem comportamentos considerados "mais femininos". Nesses casos, a sexualidade é posta em xeque por conta da expressão de gênero e, pejorativamente, utilizam-se apelidos estigmatizantes. O mesmo com mulheres com comportamentos "masculinizados". Cabe ressaltar que os exemplos aqui expostos falam de expressões de gênero, onde os discursos de ódio contidos nos termos "bicha” e "sapatão" expressam algo que não pode ser verificado, pois não há uma relação direta entre expressão de gênero e orientação sexual. Assim, o que esses exemplos nos mostram são o constante movimento estigmatizante e violento empregado para a manutenção da normatividade, que rejeita toda expressão subalterna a este modelo.

As referências à violência de gênero estão, em geral, relacionadas às práticas de violência contra as mulheres. Contudo, também homens podem ser vítimas em situações de constrangimento de violência por consequência de sua expressão de gênero. $\mathrm{O}$ controle sobre os corpos tangencia tanto mulheres quanto homens, e diversas são as formas de recriminações: "homem não chora”; "mulherzinha”; "viado", são apenas alguns exemplos possíveis.

Essas formas de violência costumam ter sua origem nos estereótipos de gênero, ou seja, no que é planejado e almejado para o sujeito desde o nascimento, como vimos anteriormente. Uma forma de equalizar esses estereótipos é uma educação que aponte para o fato de que esses preconceitos tratam de imagens preconcebidas e, por isso, necessariamente incompletas, limitadas, essencializadas.

Os estereótipos também desenvolvem uma classificação dos corpos e dos afetos. Ou seja, está imbricado em um processo valorativo, que organiza hierarquicamente apontando para características que devem ser consideradas melhores e outras que devem ser consideradas piores. Quando se reforça, na escola - mas não apenas -, que algo é correto e bom (como, por exemplo, ser heterossexual), podemos acabar por ligar, pela oposição, o fato da homossexualidade ser algo errado e ruim. Assim, a sala de aula deve ser entendida como um espaço de mediação constante, no qual os discursos se reconstroem e podem, com isso, romper com os preconceitos. Nessa mediação, os conceitos e suas consequências devem ser pensados ao extremo. Falar de heterossexualidade, por exemplo, deve abrir espaço para a discussão de suas consequências em uma sociedade injusta: o sexismo, conduta que aponta para papéis pré-estabelecidos para homens e mulheres, não possibilitando outras expressões de gênero; e o heterossexismo, que considera apenas a heterossexualidade como expressão legitima da sexualidade, ignorando as experiências gays, lésbicas e bissexuais. 
Essas duas condutas estão apoiadas na heteronormatividade, o que gera violência e restringe direitos básicos dos sujeitos. É perceptível na legislação brasileira, por exemplo, uma série de sanções para casais não-heterossexuais, como o direito ao casamento ou à adoção. A oficialização da união civil se deu apenas em 2013, e não em todo território nacional. Deste modo, o papel da escola é produzir uma pedagogia do respeito (Junqueira, 2009), que mostre a escola como espaço de possibilidades para o aprendizado através da diversidade (Perez Gomez, 1998; Silva, 1999).

\section{Os livros didáticos e os estudos de gênero}

Para o desenvolvimento da investigação, buscamos tabular os capítulos destinados aos estudos de gênero e sexualidade nos seis livros aprovados pelo Plano Nacional do Livro Didática (triênio 2015-2017), como consta na tabela abaixo.

Tabela 1: livros didáticos aprovados pelo PND 2015 com suas respectivas unidades destinadas aos Estudos de Gênero e Sexualidades. Produção das autoras

\begin{tabular}{|c|c|c|c|}
\hline Título do Livro & $\begin{array}{l}\text { Editora e ano da } \\
\text { publicação }\end{array}$ & Nome de autoras/es & Seção Gênero e Sexualidade \\
\hline Sociologia & $\begin{array}{l}\text { Scipione/ } \\
\text { Ano: } 2013\end{array}$ & $\begin{array}{l}\text { Silvia Maria de Araújo, Maria } \\
\text { Aparecida Bridi, BenildeLenzi } \\
\text { Motim }\end{array}$ & $\begin{array}{l}\text { Capítulo } 03 \text { - A família no } \\
\text { mundo de hoje }\end{array}$ \\
\hline Sociologia Hoje & $\begin{array}{l}\text { Editora Ática/ } \\
\text { Ano: } 2014\end{array}$ & $\begin{array}{l}\text { Igor José Machado; Henrique } \\
\text { Amorim; Celso Rocha de } \\
\text { Barros }\end{array}$ & Fragmentado. \\
\hline $\begin{array}{l}\text { Sociologia para } \\
\text { jovens do século XXI }\end{array}$ & $\begin{array}{l}\text { Imperial Novo } \\
\text { Milênio - } 2013\end{array}$ & $\begin{array}{l}\text { Luiz Fernandes de Oliveira; } \\
\text { Ricardo Cesar Rocha da Costa }\end{array}$ & $\begin{array}{l}\text { Capítulo } 18-\text { Gênero e } \\
\text { Sexualidade no mundo de hoje }\end{array}$ \\
\hline $\begin{array}{l}\text { Tempos modernos, } \\
\text { tempos de sociologia }\end{array}$ & $\begin{array}{l}\text { Editora do Brasil } \\
-2013\end{array}$ & $\begin{array}{l}\text { Helena Bomeny, Bianca } \\
\text { Medeiros, Raquel Calmant } \\
\text { Enrique, Julia O’Donell }\end{array}$ & Fragmentado \\
\hline $\begin{array}{l}\text { Sociologia em } \\
\text { Movimento }\end{array}$ & Moderna - 2013 & $\begin{array}{l}\text { A. Silva, B. Loureiro, C. } \\
\text { Miranda, F. Ferreira J. Aguiar, } \\
\text { L. Ferreira, M. Serrano, M. } \\
\text { Araújo M. Costa, M. Nogueira } \\
\text { O. Oliveira, P.Menezes, R. } \\
\text { Corrêa, R. Ruiz, R.Pain, R. } \\
\text { Lima, T.Bukowitz, T. Esteves, } \\
\text { V. Pires. }\end{array}$ & $\begin{array}{l}\text { Capítulo } 14-\text { Gênero e } \\
\text { sexualidade }\end{array}$ \\
\hline $\begin{array}{l}\text { Sociologia para o } \\
\text { Ensino Médio }\end{array}$ & Saraiva, 2013 & Nelson DaciTomazi. & Fragmentado \\
\hline
\end{tabular}

As informações sistematizadas na tabela acima apontam para dois movimentos que parecem marcar os livros didáticos aprovados no PNLD 2015: embora em todos os livros encontremos a emergência dos temas que circundam o campo dos estudos 
de gênero e sexualidade, é apenas na metade (três livros, dos seis aprovados) onde identificamos capítulos integralmente destinados à temática.

É ainda curioso pensar como os temas aparecem nesses três capítulos (dos livros Sociologia, Sociologia em Movimento e Sociologia para Jovens do Século XXI): nos dois primeiros livros encontramos os conteúdos de gênero e sexualidade atrelados à temática da família. É perceptível que estes assuntos são trabalhados com seriedade pelas autoras e autores responsáveis, mas mesmo assim é curioso repararmos na manutenção de uma estrutura antiga na nossa sociedade, a família.

Ao mesmo tempo, em livros que não destinam capítulos exclusivos aos estudos de gênero e sexualidade podemos encontrar, por exemplo, em um capítulo sobre violências e direitos, um apêndice com o texto da lei Maria da Penha, lei de combate a violência contra as mulheres. Deste modo, nos parece bastante complexo encontrar uma estratégia para "medir" a forma com a qual estes livros trabalham com as problemáticas do campo. Assim, com finalidade de recorte da investigação, optouse por dedicar-se aos livros didáticos nos quais podem ser encontrados capítulos inteiros destinados à problemática de gênero e sexualidade.

Para tanto, buscamos listar as autoras e os autores, além de propor uma breve discussão conceitual, com os quais estes livros didáticos trabalham na confecção de suas referências. Com isso, buscamos situar de forma histórica estes livros dentro de um campo de conhecimento. Num segundo momento, focamos nossa análise nas figuras e ilustrações utilizadas ao longo dos capítulos destinados aos estudos de gênero e sexualidade, na tentativa de compreensão de como estas criam um imaginário coletivo e formam subjetividades nas e nos estudantes de Ensino Médio no Brasil contemporâneo.

\section{Analise dos dados}

Na tabela abaixo, podemos encontrar as autoras e autores referenciados nos livros Sociologia, Sociologia em Movimento e Sociologia para jovens do século XXI, livros nos quais encontramos capítulos completos destinados aos estudos de gênero e sexualidade:

Tabela 2: Autoras/es mencionados em livros com capítulos completos destinados aos estudos de Gênero e Sexualidades. Produção das autoras

\begin{tabular}{|l|l|}
\hline Livro & Autoras/es citadas/os \\
\hline Sociologia & $\begin{array}{l}\text { Anthony Giddens; Bourdieu; Durkhein; Maria LuizaHeilborn; Russel } \\
\text { Parry Scott. }\end{array}$ \\
\hline Sociologia em Movimento & $\begin{array}{l}\text { Cristina Brueschini; Sylvie Schweitzer; Angela Davis; Elisabeth Souza } \\
\text { Lobo; Michel Foucault; Judith Butler. }\end{array}$ \\
\hline Sociologia para jovens do século XXI & $\begin{array}{l}\text { Luiz Mott; Deborah Blum; Joan Scott; AlexandreBortolini; Michael } \\
\text { Foucault; Simone de Beauvoir; Betty Friedman; Kate Millet; } \\
\text { Shulamith Firestone; bell hooks; Juliet Mitchell; Alfred Kinsey. }\end{array}$ \\
\hline
\end{tabular}


Embora encontremos unidades destinadas aos estudos de gênero e sexualidade nestes três livros, os problemas aparecem colocados de forma bastante distinta. Encontramos, no primeiro livro (Sociologia), um viés da discussão sobre gênero e sexualidades através da instituição família - o que dá título ao capítulo, A Família no Mundo de Hoje.

Ao longo deste capítulo, há grande diálogo com a teoria sociológica clássica (Durkheim) e com autores de síntese, como Giddens e Bourdieu. Embora ambos os autores tenham escrito sobre a família e gênero como Giddens e o seu $A$ Transformação da Intimidade ou Bourdieu e o seu A Dominação Masculina, trabalhos lidos pelo campo de estudos de gênero e sexualidade, mas que não são propriamente teóricos vinculados a uma epistemologia feminista. O livro didático também se aproximará de autores contemporâneos que compõem o campo no Brasil, Maria Luiza Heilborn e Russel Parry Scott. Estes autores, entretanto, têm preocupações voltadas às formas da família no Brasil contemporâneo e suas variações com outras interseccionalidades. É então curioso que haja um movimento de, primeiramente, uma mirada na direção de clássicos da sociologia para definir o conceito de família e que, em seguida, busquem-se teóricos que desenvolvem pesquisas mais voltadas à antropologia/etnografia no Brasil contemporâneo sobre o mesmo tema, mas que são utilizados, de certa forma, como "exemplificação" de variações da noção de família. É de se notar, então, que a teoria fundamental utilizada ao longo do capítulo não tem uma necessária vinculação com o campo dos estudos de gênero e sexualidade e seus preceitos epistemológicos.

O movimento realizado no livro Sociologia em Movimento é, mesmo que bastante distinto, algo próximo do que encontramos no livro Sociologia. Embora neste texto encontremos teóricas feministas de grande relevância, como Judith Butler, Angela Davis, Michel Foucault e outras, ponto no qual se diferencia do livro anterior, há de notar uma grande vinculação com as teóricas feministas de base marxista, preocupadas com a questão do trabalho, como Cristina Brueschini e Sylvie Schweitzer, principalmente, mas também Angela Davis, preocupada com o problema da classe. Também ao trazer a reflexão ao Brasil, encontramos referência aos escritos de Elisabeth Souza Lobo, socióloga preocupada com a classe trabalhadora e com a divisão sexual do trabalho. Pode-se notar, pois, um capítulo focado em um único tema, não transmitindo, novamente, a ideia de um campo de conhecimento com segmentos diversos.

Deste modo, esses dois livros apontam para uma vinculação dos estudos de gênero e sexualidade a linhas de pesquisa e reflexão bastante específicas: o primeiro, às questões de parentesco (desconstruindo a ideia de família, mas limitando-se a esta discussão); o segundo, às reflexões sobre a divisão sexual do trabalho (focando no movimento feminista classista). É apenas no terceiro livro, Sociologia para Jovens do Século XXI, que encontramos, diferentemente dos outros, ao discutir as problemáticas do campo em um capítulo intitulado Gênero e Sexualidades, um maior leque de autoras e referências de forma direta e indireta, buscando constituir o cenário de um campo que contempla linhas e segmentos, pluralidades teóricas. 
Neste livro, parece existir uma preocupação em apresentar os conceitos de forma histórica, onde encontramos teóricas de extrema relevância para o campo, como Simone de Beauvoir e Joan Scott, ao pensar gênero; e Foucault, ao pensar sexualidade. Há, entretanto, outra característica curiosa, que é a aparição de teóricos que não são das áreas das Ciências Sociais, embora também tenham se preocupado com a sexualidade. Se tomarmos a psicologia como exemplo, encontramos os estudos de Alfred Kinsey e as estatísticas da sexualidade. Ainda mais um movimento histórico parece ser relevante neste livro, e se dá ao mostrar a historicidade e o desenvolvimento dos conceitos, que pode ser pensado, por exemplo, ao apresentarse Luiz Mott como uma pessoa importante na edificação do campo dos estudos de gênero e sexualidade no Brasil, embora se apresente os desdobramentos posteriores do campo e das reflexões, especialmente por meio de Alexandre Bertollini. Por fim, um grande diferencial deste texto parece ser a referência ao movimento feminista e a noção de interseccionalidade. São trabalhadas perspectivas de autoras como Deborah Blum, Betty Friedman, Kate Millet, Juliet Mitchell, Shulamith Firestone, além de bellhooks e seu feminismo negro. Deste modo, parece existir uma tentativa de análise histórica dos conceitos ao longo de todo o capítulo, realizado com bastante seriedade - seriedade esta que se encontra de acordo ao percebermos que se nomeia o capítulo com o título Gênero e Sexualidades no mundo de hoje, onde não devemos esquecer que a constante referência a ideia de família marcada em outros textos pode ser uma tentativa de disfarçar a temática.

O que podemos reparar na comparação entre estes três livros é que os estudos de gênero e sexualidade podem ser abordados de maneira bastante distinta por meio das escolhas ético/políticas das autoras e autores de livros didáticos.

\section{Análise das figuras}

O livro Sociologia é composto por onze capítulos e, dentre estes, um intitula-se A família no mundo de hoje. Este capítulo é composto por 24 figuras, entre ilustrações, desenhos e fotografias que produzem representações do conteúdo abordado. Dentre estas, nos interessou dar ênfase especial a quatro, tendo em vista seu maior impacto visual e, principalmente, pela maneira com a qual o próprio livro lida com estas, utilizando-as não apenas como meras ilustrações (como ocorre na maioria dos casos), mas abrindo discussões reflexivas sobre gênero e sexualidade a partir das imagens postas.

A primeira imagem selecionada trata da multiplicidade de composições sobre o que entendemos como "família", ou seja, trata de uma compilação de fotografias nas quais aparece uma família composta por uma mãe, uma avó e um neto; outra formada por pai e filho; uma terceira e uma quarta constituídas por diferentes etnias indígenas, uma do Mato Grosso e outra da Amazônia; outra na qual a família é representada por um casal gay com filhas; e uma última por avó, mãe e filhas. 
Portanto, ao trazer famílias formadas das mais variadas maneiras, o livro busca atribuir novo significado à ideia da família nuclear tradicional (pai, mãe e filhos), mostrando como, na verdade, é bastante comum nos dias de hoje encontrarmos diferentes maneiras de composição familiar. A ideia, nos parece, é que, ao partir das fotografias, possa-se gerar uma reflexão sobre como cada aluna/o pensa a própria família e a dos colegas, podendo fazer com que estes englobem as inúmeras maneiras de constituição familiar ao seu próprio conceito sobre essa instituição, não abarcando apenas aquela composta por um núcleo tradicional, mas que todas as mais variadas composições façam parte do imaginário social.

Essa imagem parece ter bastante ligação com a imagem subsequente, na qual podemos encontrar uma família nuclear tradicional de São Paulo. O recurso de apresentar primeiramente famílias entendidas como "subalternas" pelos estudantes e, depois, aquela típica "família patriarcal brasileira”, conhecida por todos, parece bastante interessante por buscar desnaturalizar o que é entendido como "comum" ou "normal" pelas e pelos estudantes, tratando primeiro da multiplicidade enquanto algo "normal" e não o padrão fechado da instituição familiar, alargando sua compreensão - porém, sem deixar de se apoiar nesta.
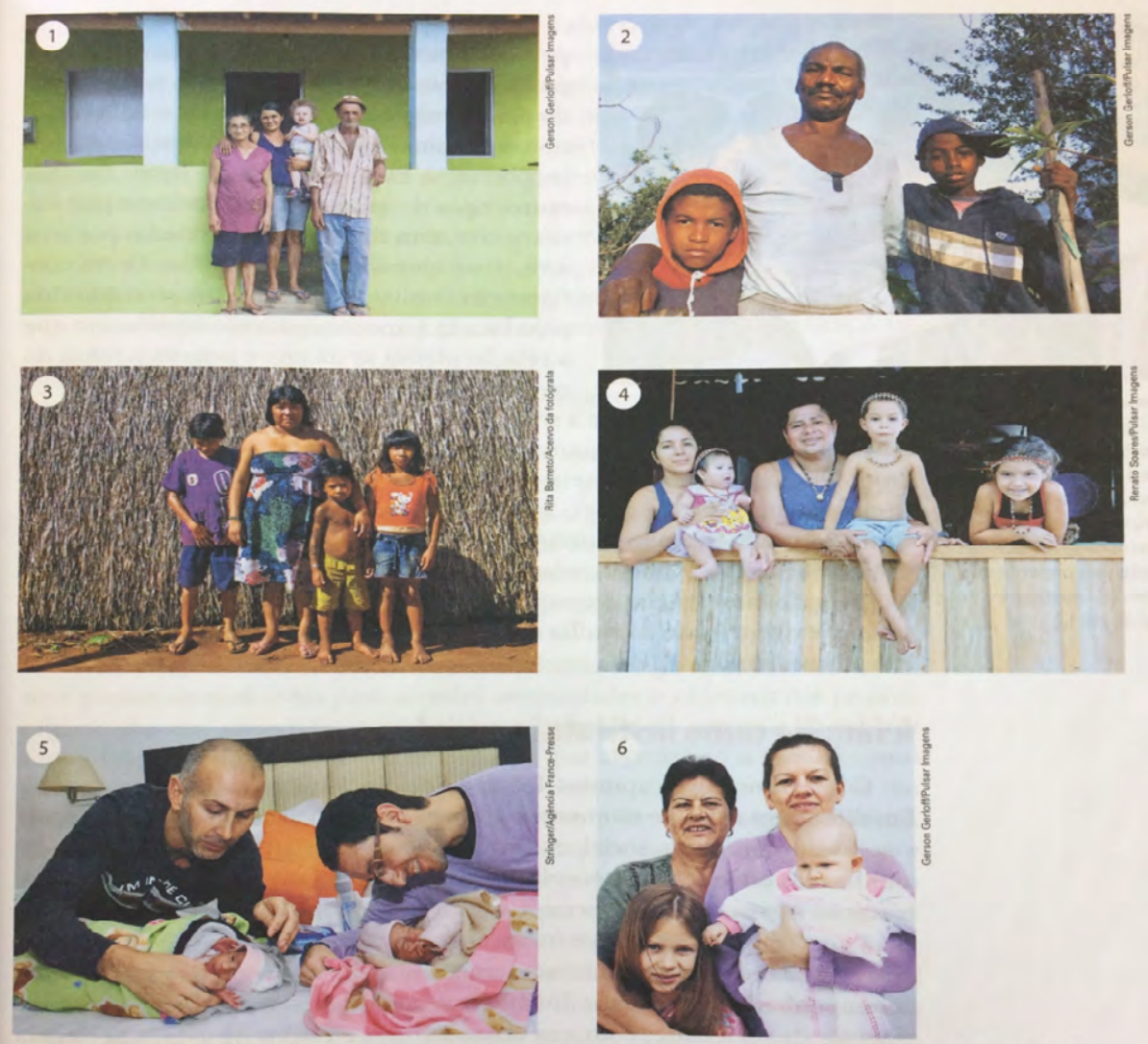

Não há um único modelo de família, podendo variar o número de membros e a composiçăo de cada uma, como podemos ver nestas imagens: 1. Três geraçōes numa mesma foto: avós, mãe e neto representando uma familia de Custódia (PE). Imagem de 2011. 2. Pai e filhos na zona rural de Restinga Seca (RS). Foto de 2011. 3. Famillia da etnia Kuikuro no Parque Indígena do Xingu (MT). Foto de 2012. 4. Familia da etnia Kambeba em Manaus (AM). Foto de 2011. 5. Casal homoafetivo espanhol com filhas recém-nascidas em hospital na India. Foto de 2011. 6. Uma familia de Santa Maria (RS) composta por avó, mãe e filhas. Foto de 2010.

(Figura 1. Fonte: Livro Sociologia) 


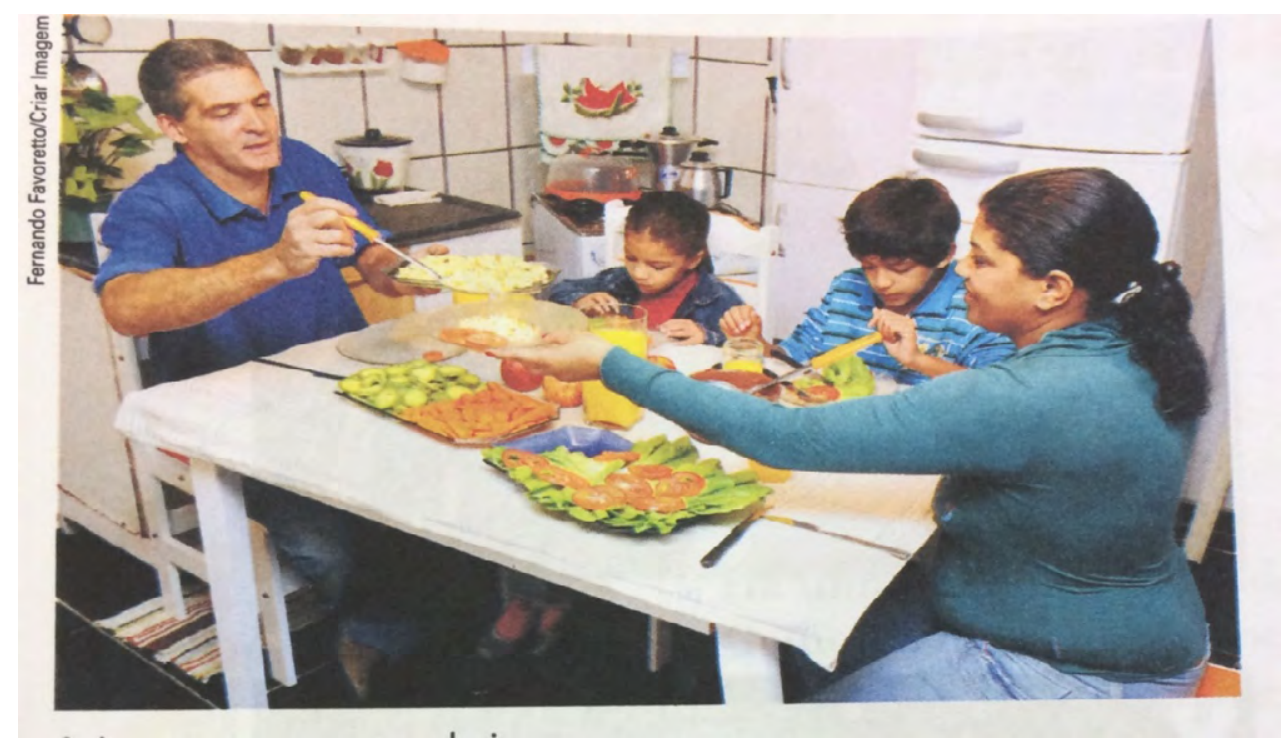

(Figura 2. Fonte: Livro Sociologia)

Outra figura relevante que encontramos neste capítulo apresenta manifestações do dia 8 de março de 2012, em São Paulo, trazendo a importância do dia internacional da mulher e visibilizando as batalhas diárias do que significa ser mulher no Brasil. Ao inserir essa fotografia como gancho para um debate, o livro busca instigar a reflexão sobre a importância das lutas do movimento feminista e como as reivindicações por direitos, condições de trabalho e o fim da violência de gênero são temas de extrema relevância em nossa sociedade.

Dessa maneira, propõe-se uma reflexão sobre a manifestação e sua importância, rompendo com alguns preconceitos sobre o movimento feminista, abordando a realidade das desigualdades e violências sofridas pelas mulheres brasileiras e a necessidade de combatê-las. Por meio do recurso dessa imagem, na qual aparecem representantes de várias gerações, vestidas de roxoe segurando cartazes, podese pensar em como instigar as e os estudantes sobre as lutas por direitos, fazendo com que estes entendam a importância das articulações e movimentos sociais em processos de construção democrática. 


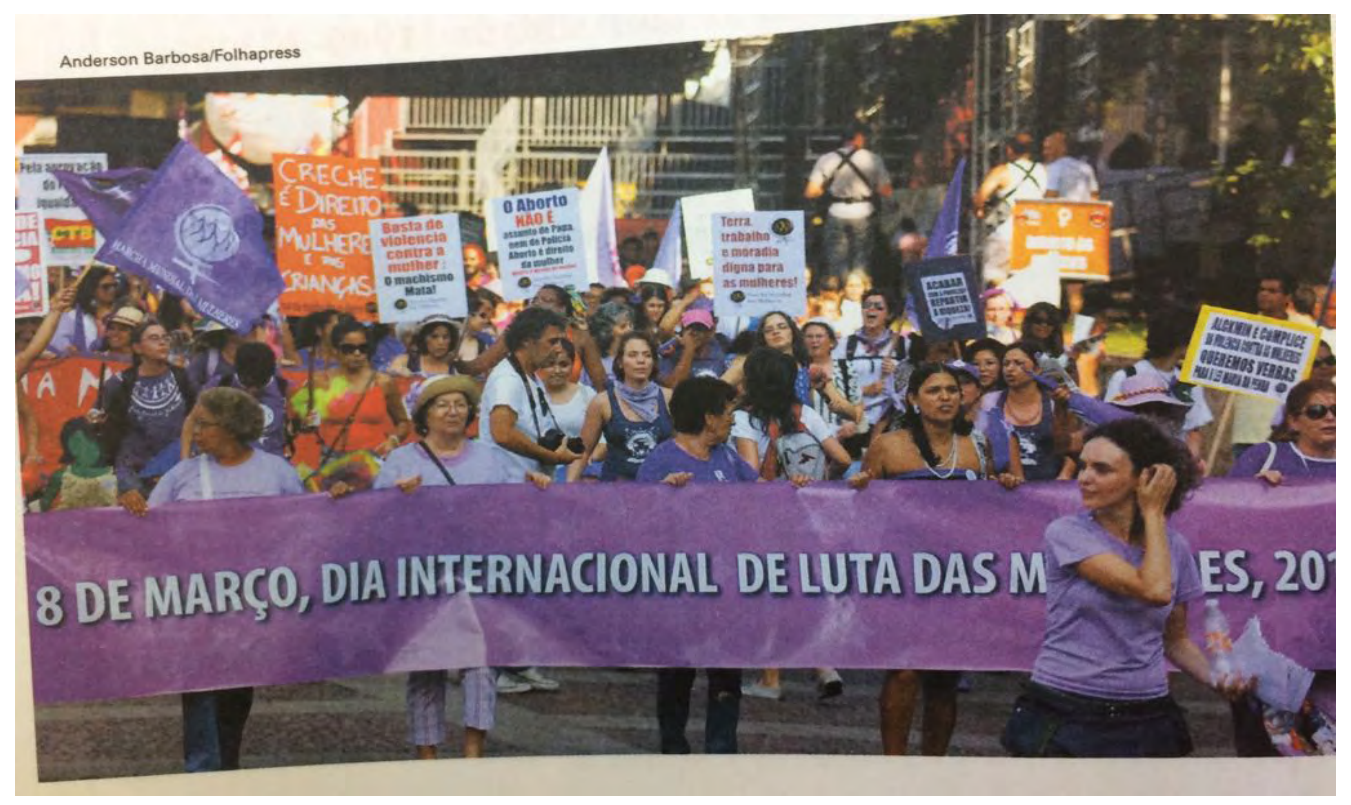

(Figura 3. Fonte: Livro Sociologia)

Uma última figuraque parece interessante abordar trata da temática do casamento gay. Ao expor uma foto do primeiro casal homossexual a formalizar juridicamente seu casamento no país, o qual se deu no estado de São Paulo em junho de 2011, apresenta-se a discussão sobre como apenas neste ano (2011) foi possível no Brasil a concretização civil da união, além de expor as imensas dificuldades em torno do casamento gay e da heterossexualidade compulsória (Rich, 2010), permeados por inúmeros preconceitos. Ao buscar uma reflexão a respeito das dificuldades dos casais homossexuais e como essas são geradas muitas vezes por se acreditar numa instituição familiar normativa, a imagem possibilita compreender a luta do movimento LGBT em busca de direitos. Interessante notar que, por meio disso, vemos a manutenção do tema principal do capítulo: a família, trazendo concepções críticas e propondo a desnaturalização desta concepção, além da importância das conquistas sociais em busca da afirmação da diversidade enquanto positivas e necessárias.

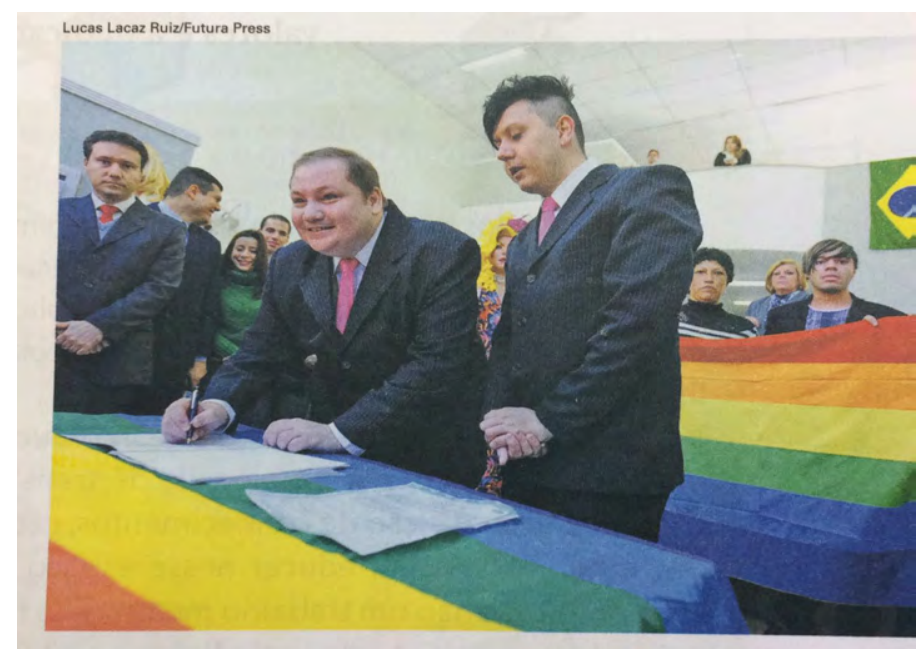

(Figura 4. Fonte: Livro Sociologia) 
O livro Sociologia em movimentoaborda os temas de nosso interesse no capítulo 15, cujo título é Gênero e Sexualidade. Nesta parte, encontramos 15 figuras, sendo elas fotografias, gráficos, tabelas e pinturas. As imagens escolhidas ilustram um resumo do que é abordado ao longo do capítulo, para elucidar as desigualdades sofridas pelas mulheres no mercado de trabalho e na sociedade.

Como exemplo, encontramos nas primeiras figuras a relação das mulheres e o mercado de trabalho. Em uma das ilustrações vemos uma operária em meio à greve de operários em Berlim, evidenciando que, assim como os homens, as mulheres também se encontram inseridas no mercado de trabalho.

Nos gráficos seguintes, encontramos uma estimativa de trabalhadores domésticosporsexoeregiãonoanode2010,produzidapelaTheDomesticWorkPolicyBrief. Assim, podemos identificar que a maior parte deste campo de trabalhoé preenchida por mulheres, o que leva a uma interpretação dupla, que aponta a importância do trabalho doméstico para a economia, por um lado, mas também o determinismo de um campo de atuação profissional.

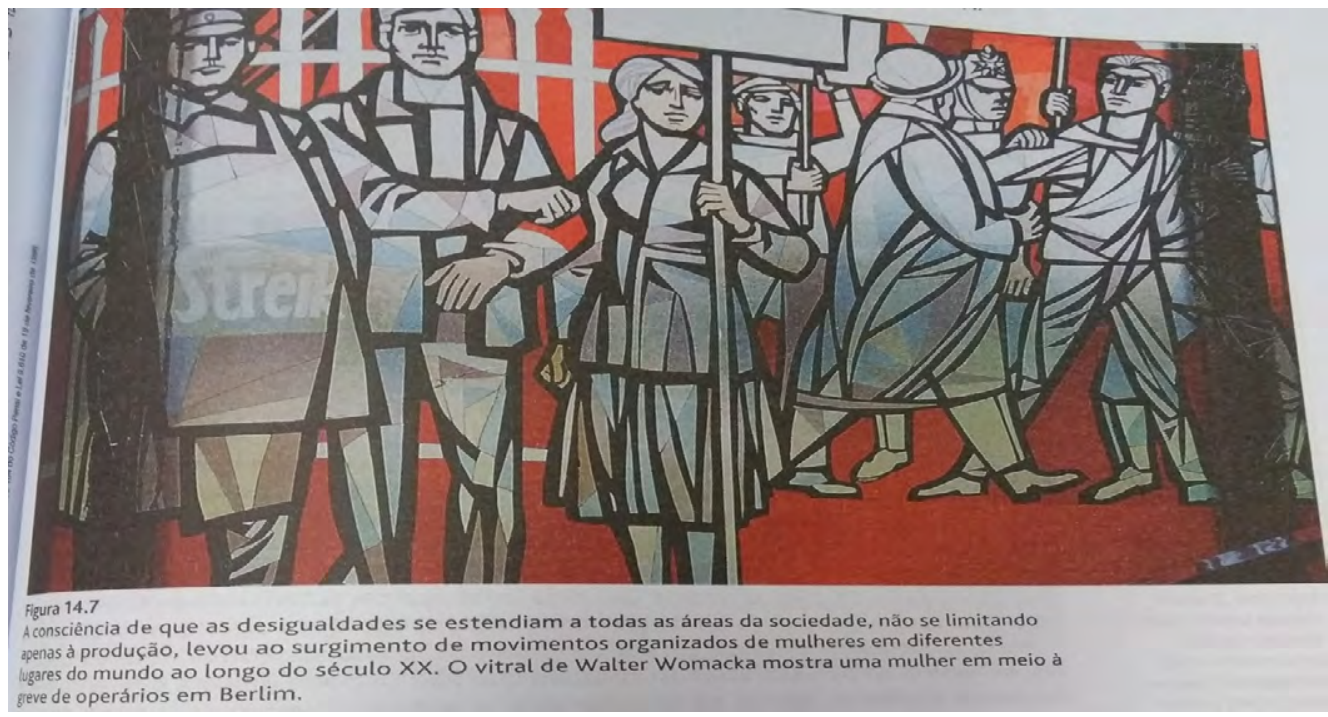

(Figura 5. Fonte: Livro Sociologia em movimento)

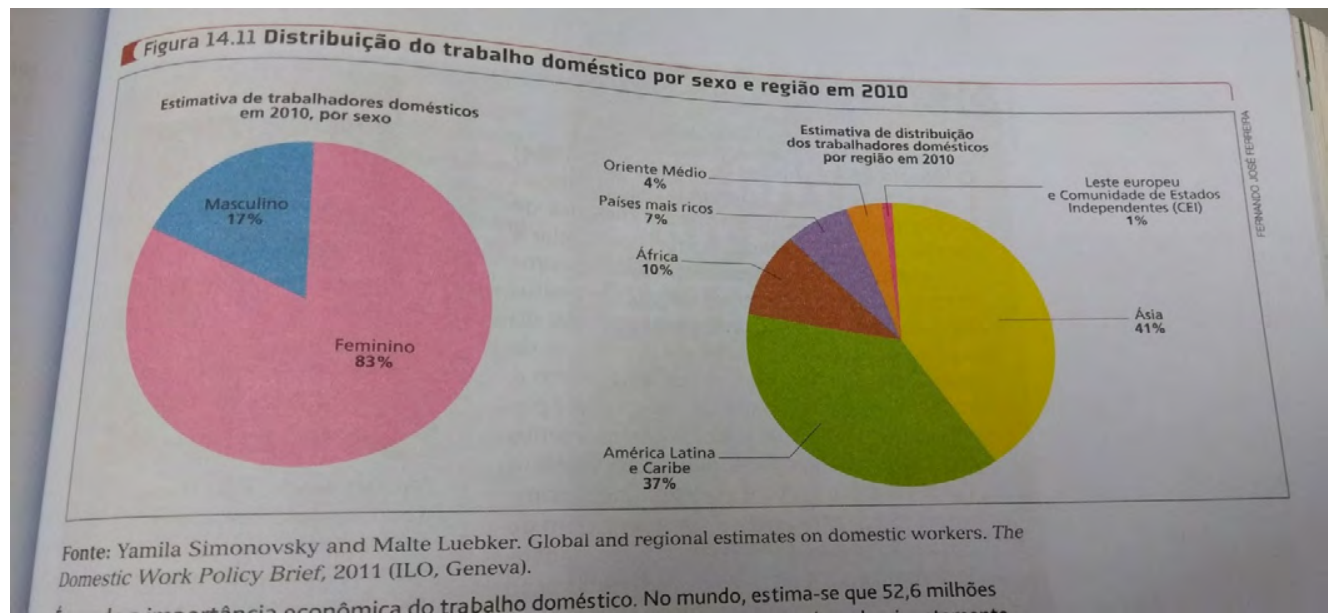

(Figura 6. Fonte: Livro Sociologia em movimento) 
Essas duas imagens mostram, ao mesmo momento, a inserção das mulheres no mercado de trabalho e a vinculação dessas mulheres em lutas por direitos trabalhistas. Como já apontado, entretanto, não temos acesso a uma reflexão propriamente sobre movimentos de mulheres/feministas, mas encontramos as reflexões sobre engajamento feminista diluídas no movimento operário e as configurações de gênero vinculadas às problemáticas do trabalho.

Também a presença de mulheres na política é discutida ao longo deste capítulo, como pode ser visto na imagem a seguir, em que encontramos expostos os índices da participação de mulheres na Câmara dos Deputados e no Senado em diversos países, mostrando as taxas e a porcentagem de participação onde há maior e menor participação política feminina. Há de se ressaltar o percentual brasileiro, que é de 8,6\% na Câmara dos Deputados, e de $16 \%$ no Senado. Destaque, ainda, para Ruanda como país com maior participação de mulheres, e o Haiti com a menor delas.

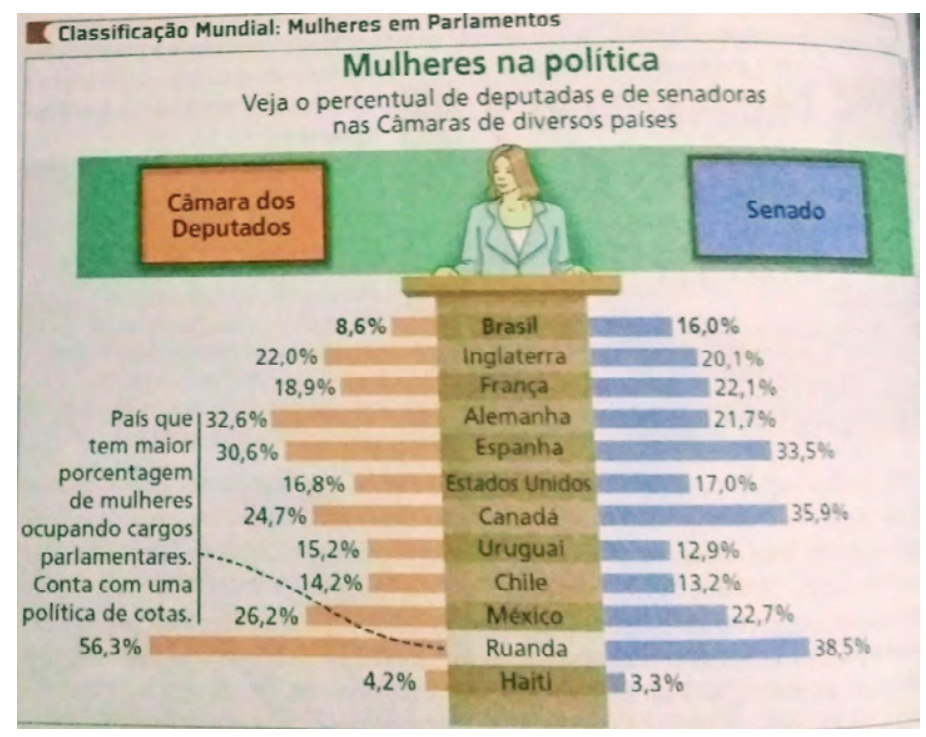

(Figura 7. Fonte: Livro Sociologia em movimento)

Essas comparações entre os gêneros também aparecem em documentos como, por exemplo, a distinção salarial entre homens e mulheres no Brasil, dentre outros, mas que geralmente tendem a lidar com a problemática pelas chaves do trabalho.

Já o livro Sociologia para jovens do século XXIapresenta em seu capítulo Gênero e Sexualidade no mundo de hojeum total de 12 ilustrações, entre elas gráficos, fotografias e charges. Também desse livro quatro foram as figuras escolhidas para destrincharmos aqui. A primeira é uma fotografiaque traz uma faixa da Marcha Mundial das Mulheres, na qual podemos ver o desenho de cinco mulheres de diversas etnias e marcas fenotípicas, de mãos dadas. Como já observado na análise das imagens do livro Sociologia, abordar o tema das lutas dos movimentos feministas nos parece de extrema relevância, seja para fortalecer a importância dessas manifestações, seja para abordar as dificuldades e desafios enfrentados diariamente pelas mulheres. Lembrando que um dos diferenciais deste livro é justamente a aparição do debate sobre os movimentos feministas, como também a presença de 
um viés de interseccionalidade. É possível por meio desta figura reconhecer estes princípios.

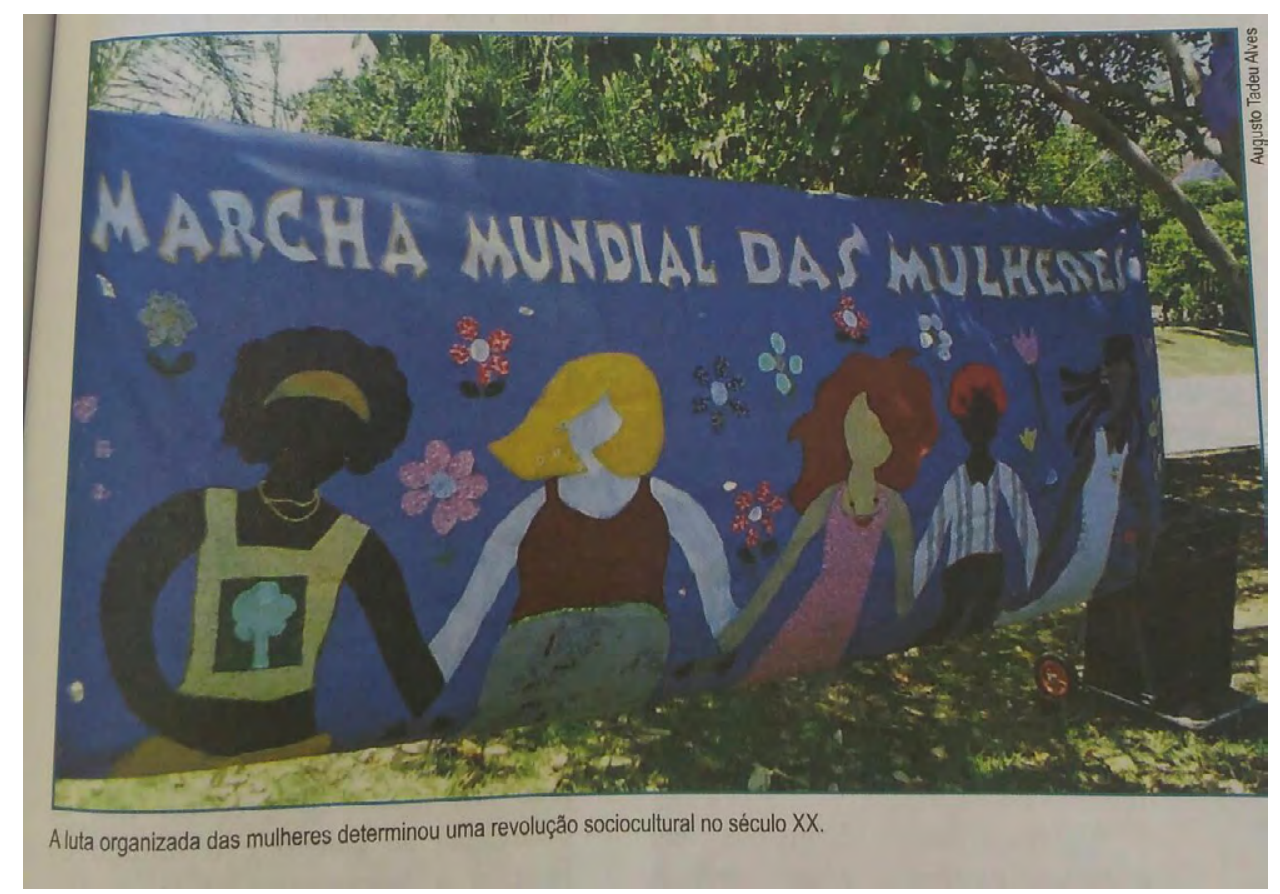

(Figura 8. Fonte: Livro Sociologia para jovens do século XXI)

A segunda imagem selecionada é um retrato de uma passeata pelo voto feminino em Nova York (EUA) no ano de 1912, onde novamente o tema do movimento feminista emerge. Nela podemos ver algumas mulheres e crianças com bandeirinhas nas mãos, marchando. $\mathrm{O}$ tema sobre a luta das mulheres pelo sufrágio universal está presente nas discussões sobre gênero há muito tempo e sua abordagem no livro didático nos permite fazer uma apresentação, um debate, mostrando a historicidade das conquistas e lutas feministas, assim como trazer as desigualdades ainda hoje encontradas no campo da representação política feminina, por exemplo. O espaço político, ainda que tenhamos conquistado o direito ao voto, é majoritariamente masculino. E isso impacta diretamente na implementação de políticas públicas que não conseguem abarcar as reais demandas das mulheres, assim como outros grupos minoritários que não são representados. 


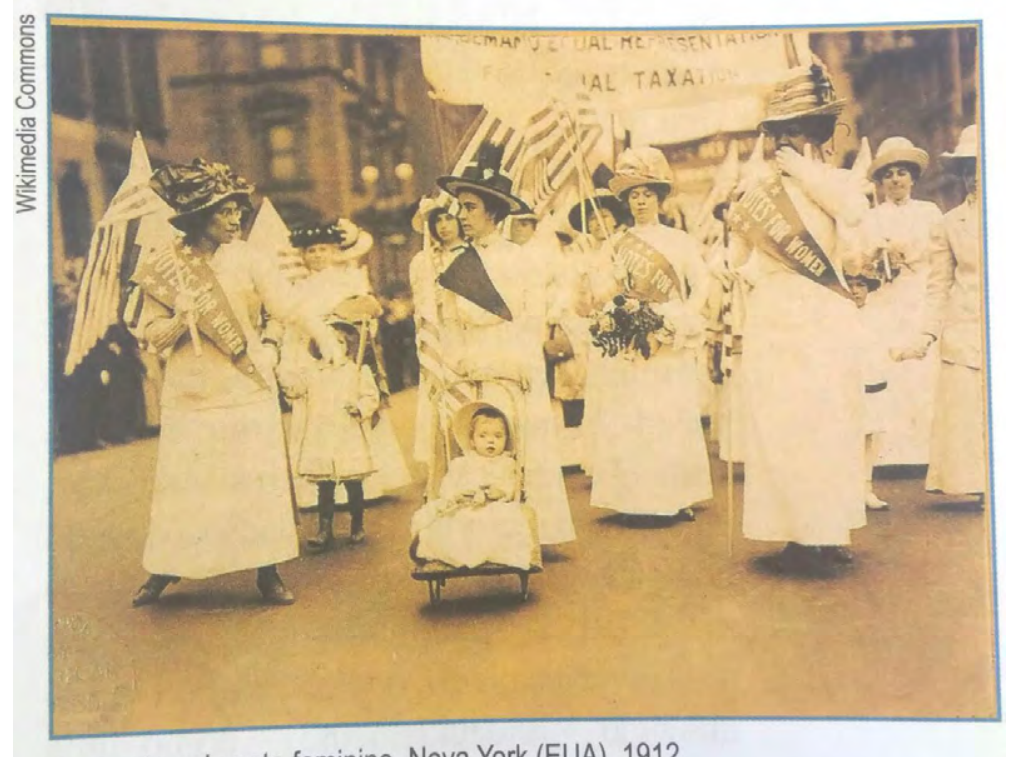

Passeata pelo voto feminino, Nova York (EUA), 1912.

(Figura 9. Fonte: Livro Sociologia para jovens do século XXI)

Já na próxima imagem selecionada temos a escritora Simone de Beauvoir em uma conferência sobre "A condição da mulher no mundo moderno", em São Paulo, no ano de 196o. Como foi dito no tópico análise de dados, outro diferencial desse livro é a sua preocupação em ampliar a variedade de autores referenciados. Dessa forma, trazer a imagem da Simone de Beauvoir, cuja importância para campo dos estudos de gênero e sexualidadeé notória, permite às professores e aos professores aprofundarem debates sobre conceitos e abordagens que muitas vezes são passadas de maneira mais superficial. Este livro ainda parece de grande relevância por apresentar a interdisciplinar que marca o campo de estudos.

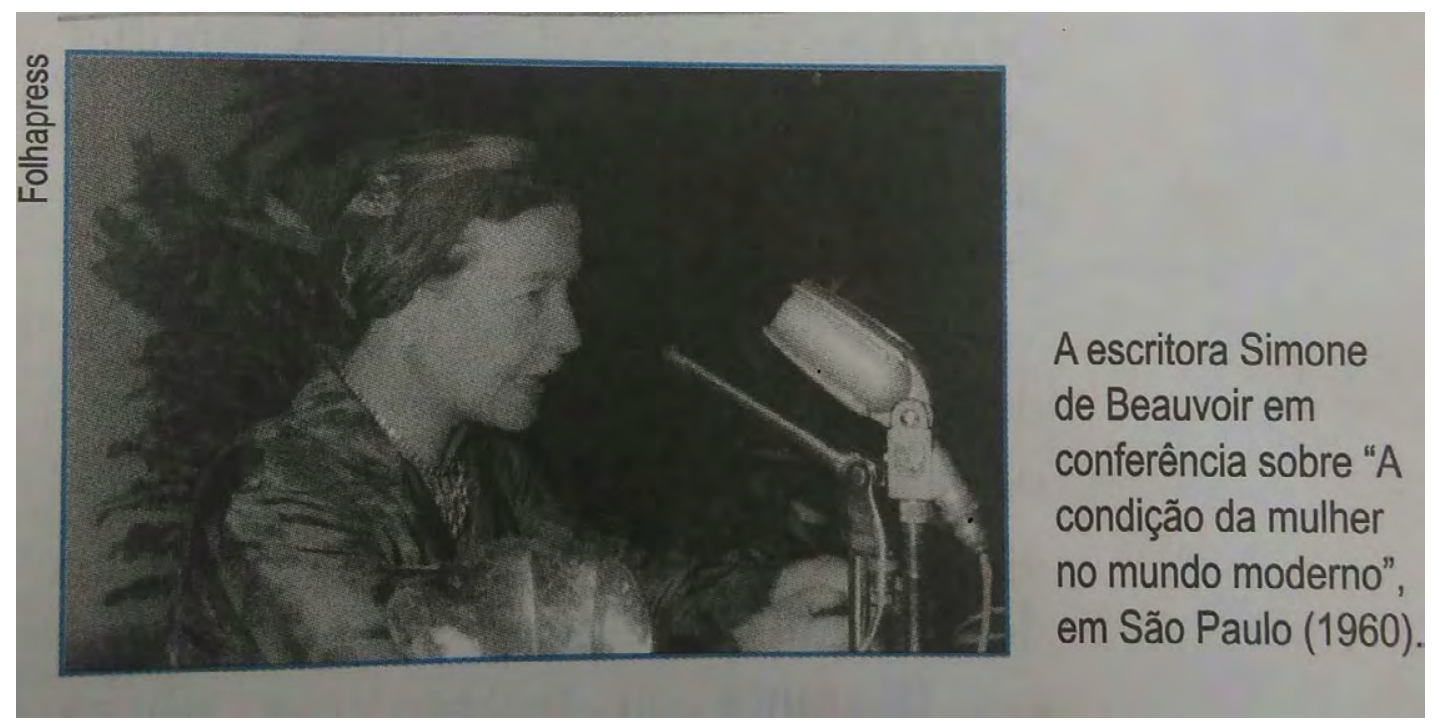

(Figura 10. Fonte: Livro Sociologia para jovens do século XXI) 
A última figura que apresentamos é um gráfico de 2011 no qual encontramos as taxas das vítimas de violência homofóbica por estado no Brasil. Sabendo que o Brasil é o país que mais mata LGBTs no mundo, 1 a cada 25 horas, a figura é de extrema importância, pois consegue expor de maneira clara números assustadores que nos ajudam a enxergar uma realidade que é invisibilizada e retratada de maneira rasa pelos meios de comunicação.

Através dele destacamos o Distrito Federal e o Piauí como as duas unidades federativas em que as taxas das vítimas de violência homofóbica são as mais altas, o Maranhão e o Ceará vindo logo atrás com taxas um pouco mais baixas, porém ainda muito elevadas. Os estados, pelo gráfico, que registraram os menores números foram: Roraima, Amapá e Acre.

Dessa forma, o gráfico nos permite abordar, alertar e questionar as alunas e alunos tanto sobre a homofobia, como os possíveis motivos para essas taxas tão elevadas de violência no nosso país, exercitando seu pensamento crítico e retificando o repúdio ao preconceito e discriminação.

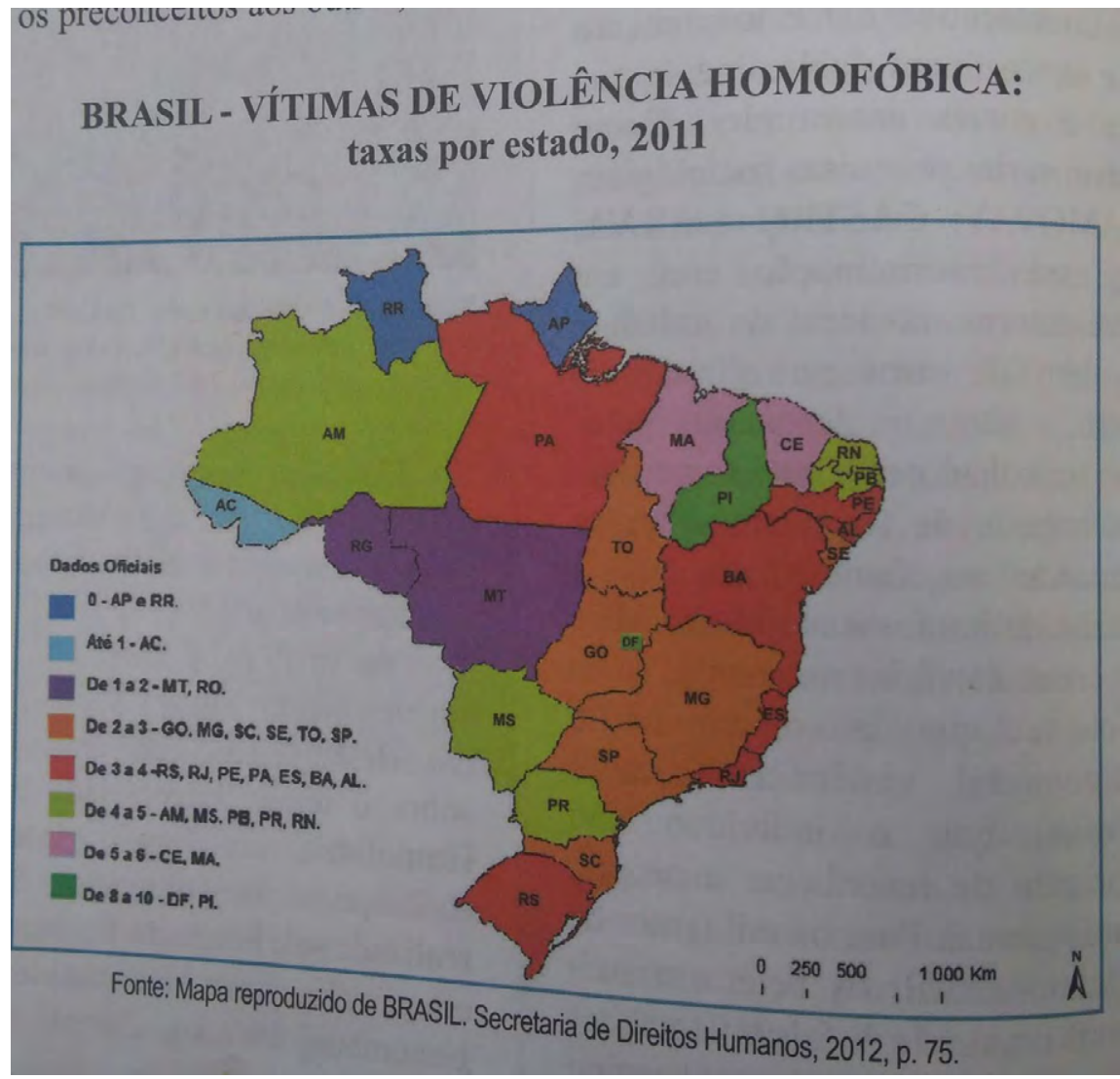

(Figura 11. Fonte: Livro Sociologia para jovens do século XXI) 


\section{Considerações finais}

Pudemos perceber, ao longo da análise, que as problemáticas de gênero e sexualidade são trabalhadas de forma bastante distinta ao longo dos seis livros aprovados pelo PNLD 2015-2017. Em três dos livros aprovados (Tempos Modernos, Tempo de Sociologia; Sociologia Hoje; Sociologia para o Ensino Médio) encontramos os temas dos estudos de gênero e sexualidade de forma pulverizada junto aos demais conteúdos. Por sua vez, nos livros Sociologia, Sociologia em Movimento e Sociologia para Jovens do Século XXI há capítulos específicos que buscam trabalhar com estes temas.

Mesmo nestes capítulos específicos, podemos encontrar linhas argumentativas bastante distintas. No livro Sociologia percebemos uma aproximação com as problemáticas de família e parentesco. No livro Sociologia em Movimento há maior direcionamento para as relações entre gênero e trabalho. Por fim, no livro Sociologia para Jovens do Século XXI podemos encontrar uma ideia melhor exposta do campo dos estudos de gênero e sexualidade, mesclando autoras clássicas com perspectivas contemporâneas, apontando para influências externas às ciências sociais, como os aportes da psicologia. Em suma, neste livro encontramos uma noção de campo de conhecimento mais desenvolvida.

Ao longo da análise, foi possível refletir sobre a necessidade dos estudos de gênero e sexualidade na escola, ao mesmo tempo em que a análise dos livros didáticos no geral apontam para a necessidade de formação externa dos professores para poder trabalhar com a temática, o que faz com que sejamos defensores de maiores investimentos em políticas públicas na educação, como cursos de especialização que foquem nas diversidades, sejam étnico/raciais, de gênero, sexualidade, dentre outras, possibilitando que a escola seja um espaço de reconhecimento da diversidade e da pluralidade, compreendendo as experiências dos estudantes e produzindo, assim, uma educação que se responsabiliza com a autonomia dos sujeitos.

\section{Referências bibliográficas}

ARAÚJO, Sílvia Maria de; BRIDI, Maria Aparecida; MOTIM, Benilde Lenzi. (2013). Sociologia. $1^{\mathrm{a}}$ Ed. São Paulo: Scipione.

BEAUVOIR, Simone. (2009). O segundo sexo. $2^{\mathrm{a}}$ Ed. Rio de Janeiro: Nova Fronteira.

BOMENY, Helena et all. (2013). Tempos modernos, tempos de sociologia. $2^{\underline{a}}$ Edição. São Paulo: Editora do Brasil.

FOUCAULT, Michel. (2004) História da sexualidade 1 - A Vontade de Saber. $1^{\mathfrak{a}}$ Ed. São Paulo: Paz e Terra. 
JUNQUEIRA, R. (2009). Homofobia nas escolas: um problema de todos. In Diversidade Sexual na Educação. Brasília: UNESCO.

LAQUEUR, Thomas. (2001) Inventando o sexo: corpo e gênero dos gregos a Freud. Rio de Janeiro: Relume Dumará.

MACHADO, Igor José; AMORIN, Henrique; BARROS, Celso Roche de. (2013). Sociologia hoje. $1^{\mathrm{a}}$ Ed. São Paulo, Editora Ática.

MEAD, Margareth. (2011). Sexo e temperamento. $4^{\text {a }}$ Ed. São Paulo: Perspectiva.

NAVARRO-SWAIN, Tania. (2006). Entre a vida e a morte, o sexo In Labrys, estudos feministas. v. 12, no: jun/dez.

OLIVEIRA, Luiz Fernandes de; COSTA, Ricardo Cesar Rocha da (2013). Sociologia para jovens do século XXI. $3^{\underline{a}}$ Edição. Rio de Janeiro: Imperial Novo Milênio.

PÉREZ GÓMEZ, Angel. (1998). As funções sociais da escola: da reprodução à reconstrução crítica do conhecimento e da experiência. In Gimeno Sacristán, J. Compreender e transformar o ensino. $4^{\underline{a}}$ Ed. ArtMed.

RICH, Adrienne. (2010) Heterossexualidade Compulsória e Existência Lésbica In Bagoas - Revista de Estudos Gays. Natal, v. 4, n. 5.

SCOTT, Joan. (1990) Gênero: uma categoria útil de análise histórica In Educação e Realidade, Porto Alegre, v.2o, n.2.

SCOTT, Joan. (1994) Prefácio Gender and Politics of History In Cadernos Pagu, nº. 3, Campinas/SP.

SPIVAK, Gayatri. (2010). Pode o subalterno falar? Belo Horizonte: Editora UFMG, 2010.

SILVA, Tomás Tadeu. (1999). Documentos de Identidade: uma introdução às teorias do currículo. Belo Horizonte: Autêntica.

SILVA, Afrânio et all (2013). Sociologia em Movimento. $1^{\text {a }}$ Ed. São Paulo: Moderna.

TOMAZI, Nelson Daci. (2013). Sociologia para o ensino médio. $3^{\text {a }}$ edição. São Paulo: Saraiva.

VELHO, Gilberto. (2013)Um Antropólogo na cidade: ensaios de antropologia urbana. $\mathbf{1}^{\mathrm{a}}$ Ed. Rio de Janeiro: Jorge Zahar. 
WITTIG, Monique. (1992) The Straight Mind and other essays. Boston: Beacon Press. Tradução livre ao português disponível em: <file:///C:/Users/Cliente/ Downloads/a\%2ocategoria\%2ode\%2osexo\%2oreedi\%C3\%A7\%C3\%A3o-bklt.pdf>. Acesso em 13 nov. 2017.

Recebido: 29.03.2018

Aceito: 01.10 .2018 